\title{
Wisconsin "Chickens"
}

\section{(Tyumpanuchus cupido)}

\section{By FRED W. LAHRMAN, Saskatchewan Museum of Natural History}

At the invitation of Dr. and Mrs. $\mathrm{N}$. Hammerstrom, grouse project ders, Ralph Stueck, Wolfram Niesand I visited a Pinnated Grouse oject Study Station on March 291957, at Plainfield, Wisconsin. A ique study of this rare and vaning species is being carried out Plainfield by the Wisconsin Convvation Department; unique beuse of the extent to which the inested public is invited to particite.

Each spring, during the courtship riod when the grouse are perform$\mathrm{g}$ on their traditional dancing bunds, hundreds of university idents, photographers, bird watch$s$ and others interested in nature me to use the numerous blinds hich have been set up right in the iddle of established dancing ounds. The study benefits in this gard from the observations made visitors, but the public benefits ore. It is hoped that this publicity ill help to interest people in the elfare of the species. For nesting is grouse requires natural grass eas. Recent purchases of suitable acts as permanent nesting grounds local natural history societies and terested individuals demonstrates e effectiveness of this program.

Unfortunately, this species of ouse, the "true" Prairie Chicken "Squaretail," although once comon in southern Saskatchewan, ems to be extirpated in this area.

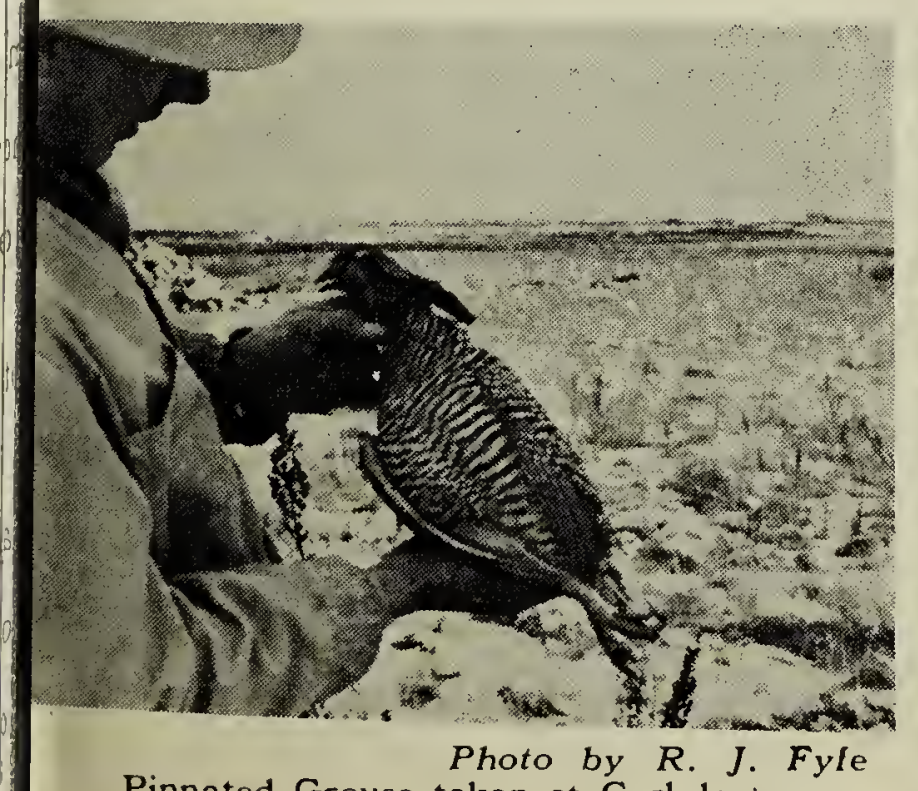

Pinnated Grouse taken at Carlyle, 31, 1945-Last known record for Sask.
Our last known report is a bird which was shot on October 31, 1945, at Carlyle, Saskatchewan, by Mr. R. J. Fyfe of Regina, while hunting sharp-tailed grouse. The habitat requirement studies in Wisconsin may well provide the clue to the re-establishment and management of the Pinnated Grouse in Saskatchewan.

If our personal experience is similar to that of others who have watched the "chickens" perform we can well understand the enthusiasm which has been aroused in Wisconsin. In the cold and utter darkness of 3:30 a.m. we crept out of our snug sleeping bags, did justice to piping hot coffee and scrambled eggs prepared by the brisk and energetic Hammerstroms-to whom this was an everyday affair-climbed into various cars and trucks and were ushered out to the blinds by $4: 30$ a.m.

At the first hint of dawn I could hear the booming of the grouse as they aproached and soon, in the gathering light, I could see fourteen grouse before my blind, each busily engaged in maintaining its own territory, fighting other intruding cocks and displaying and booming and awaiting the arrival of the hens. When the light improved after sunrise I was able to secure a number of photographs of the birds. Photos alcne can convey only a small part of our experience-but perhaps one day we'll see the real thing in Saskatchewan.

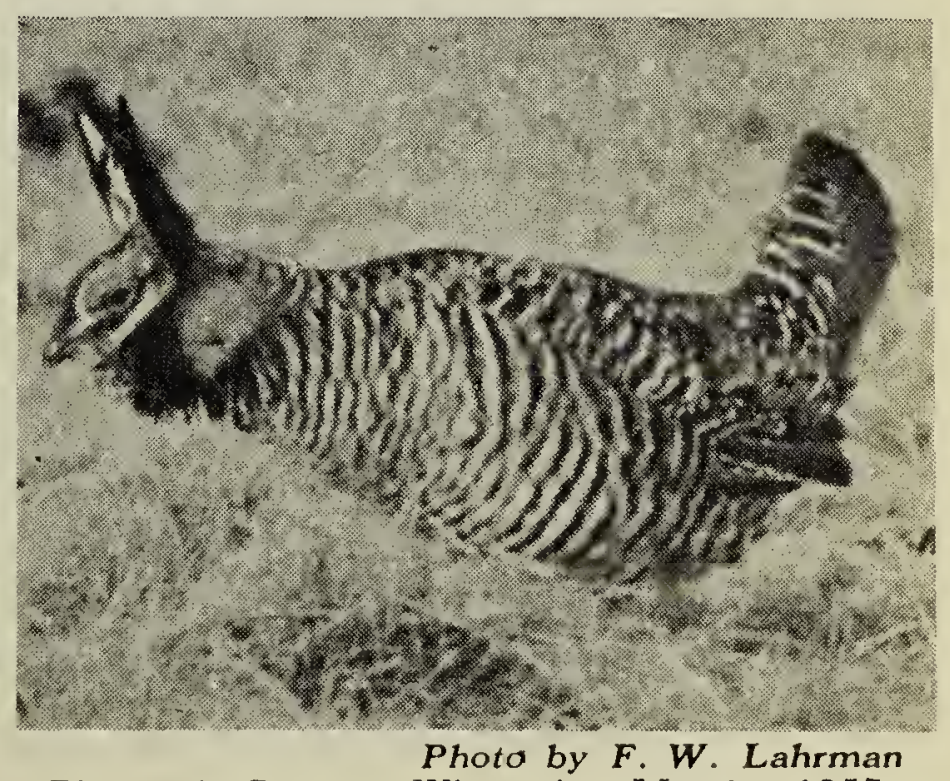

Pinnated Grouse. Wisconsin, March, 1957 